\title{
Evaluation of coal bed methane potential of coal seams of Sawang Colliery, Jharkhand, India
}

\author{
Anil M Pophare ${ }^{1, *}$, Vinod A Mendhe ${ }^{2}$ and A Varade ${ }^{1}$ \\ ${ }^{1}$ Post Graduate Department of Geology, RTM Nagpur University, Law College Square, \\ Amravati Road, Nagpur 440 001, India. \\ ${ }^{2}$ Central Mining 83 Fuel Research Institute, Dhanbad 826 004, India. \\ *e-mail: apophare@yahoo.com
}

\begin{abstract}
The coal seams of Sawang Colliery, East Bokaro Coalfields are bituminous to sub-bituminous in nature and categorized as high gaseous seams (degree II to degree III level). These seams have the potential for coal bed methane (CBM) and their maturity increases with increasing depth, as a result of enhanced pressure-temperature conditions in the underground. The vitrinite maceral group composition of the investigated coal seams ranges from $62.50-83.15 \%$, whereas the inertinite content varies from $14.93-36.81 \%$. The liptinite content varies from $0.66 \%$ to $3.09 \%$. The maximum micro-pores are confined within the vitrinite group of macerals. The coal seams exhibit vitrinite reflectance values (Ro\% calculated) from 0.94\% (sample CG-97) to 1.21\% (sample CG-119).

Proximate analyses of the investigated coal samples reveal that the moisture content $(M \%)$ ranges from $1.28 \%$ to $2.98 \%$, whereas, volatile matter (VM\%) content is placed in the range of $27.01 \%$ to $33.86 \%$. The ash content $(A \%)$ ranges from $10.92 \%$ to $30.01 \%$. Fixed carbon (FC\%) content varies from $41.53 \%$ to $55.93 \%$. Fuel ratio variation shows a restricted range from 1.53 to 1.97. All the coal samples were found to be strongly caking and forming coke buttons.

The present study is based on the adsorption isotherm experiments carried out under controlled $P-T$ conditions for determination of actual gas adsorption capacity of the coal seams. This analysis shows that the maximum methane gas adsorbed in the coal sample CG- 81 is $17 \mathrm{~m}^{3} / \mathrm{t}$ (Std. daf), at maximum pressure of $5.92 \mathrm{MPa}$ and experimental temperature of $30^{\circ} \mathrm{C}$. The calculated Langmuir regression parameters $\mathrm{P}_{\mathrm{L}}$ and $\mathrm{V}_{\mathrm{L}}$ range from 2.49 to $3.75 \mathrm{MPa}$ and 22.94 to $26.88 \mathrm{~m}^{3} / \mathrm{t}$ (Std. daf), respectively.
\end{abstract}

\section{Introduction}

India is one of the largest coal-producing countries in the world. The Gondwana and Tertiary sedimentary basins of India contain substantial coal reserves of approximately 253 billion tones spread in nearly 60 coalfields (Patra et al 1996; Acharyya 2000, 2001; Dutt et al 2001; Das Gupta 2006). The bituminous to sub-bituminous coal seams of these vast coal reserves are ideal reservoirs for the generation and accumulation of CBM. The Damodar Rift Valley in Jharkhand, Wardha Valley coalfields in Maharashtra and Satpura, Sohagpur East,
Sonhat and Sohagpur West coalfields in Madhya Pradesh contain potential resources for CBM in India (Shankaran and Bastia 1994; Narsimhan et al 1998). The presence of CBM has also been reported from bituminous coal occurring in East Bokaro Coalfields, which includes the present study area of Sawang Colliery (figure 1) (Kumar and Sahay 2001; Pophare and Varade 2004a).

The comprehensive geological assessment of coal and lignite basins of India has revealed that about $20,000 \mathrm{~km}^{2}$ of these coalfields is prospective area for CBM exploration and exploitation. The estimated gas-in-place (GIP), i.e., CBM reserves were

Keywords. CBM; adsorption isotherm; Sawang Colliery; Jharkhand. 


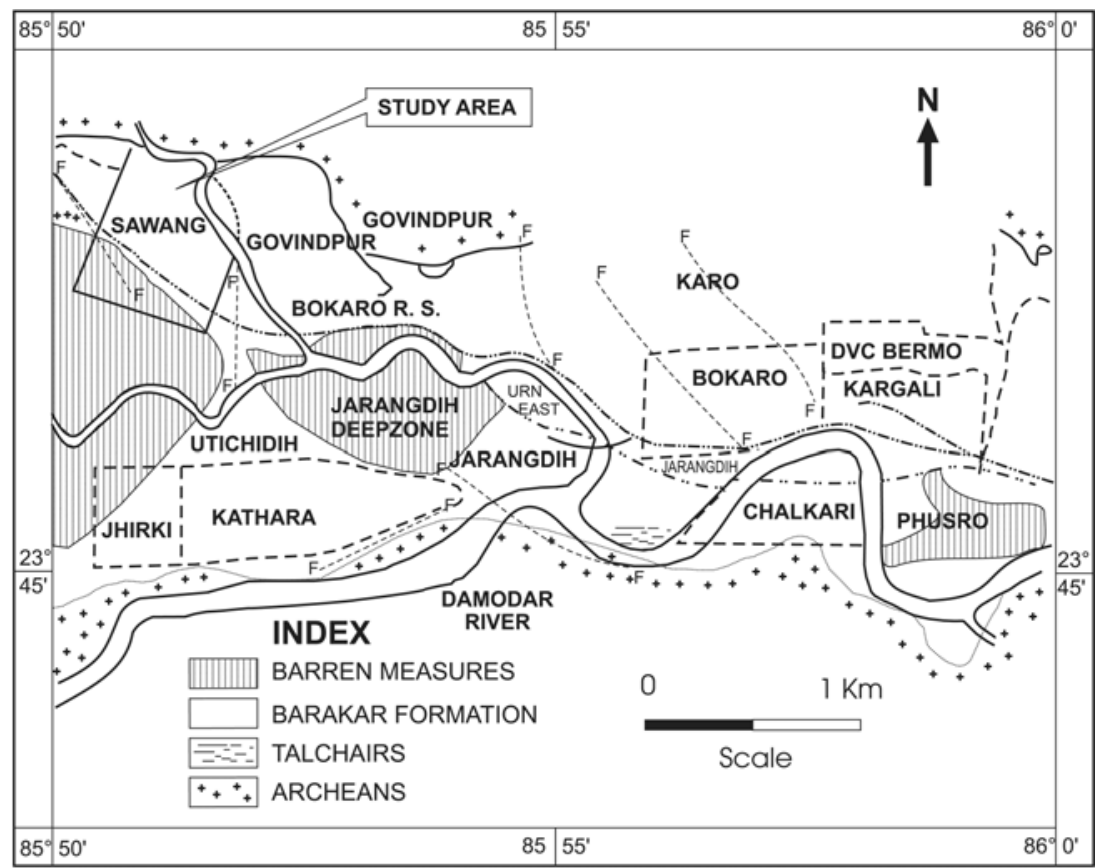

Figure 1. Geological map of the East Bokaro Coalfield showing Sawang Colliery.

placed at about 2000 to $2500 \mathrm{BCM}$ with the recoverable reserve of about 800 BCM (Acharyya 2001; Sharma and Sundaram 2001; Dutt 2007). The exploration and economic exploitation of this huge CBM resource will fulfill the future energy requirement of the country.

Since exploration of coal bed methane has gone beyond coal mining areas into undeveloped coal bearing basins, strategies of exploration require an understanding of the factors leading to concentration and accumulation of methane in the coal seams. These factors include depth and rank of coal seams, reservoir $P-T$ conditions, maceral composition of coal, proximate analysis and hydrological conditions prevailing in the area along with data on adsorption and desorption capacity of coal seams (Biswas 1995; Acharyya 2000, 2001; Yenigalla 2006).

In general, during the early stages of coalification a large amount of $\mathrm{CO}_{2}$ is generated and in later stages methane is generated (Rightmire 1984). The yield of methane and adsorption capacity of coal seams depend on its thickness, rank and maceral composition matrix (Higgs 1986; Levine 1987, 1991a, 1991b, 1992). The other parameters that influence the gas sorption capacity of coal seams are the amount of inorganic matter present, $P-T$ conditions, micro-pores, cleats and density of fracture system. The adsorption capacity of coal seams increases with increasing pressure and decreases with increasing temperature (Meisner 1984).

Adsorption of methane gas by coal seams and its relation with maceral constituents is an extremely important area of research for successful enhancement of its recovery from the coal seams. Various mechanisms have been suggested for adsorption of gases in coal seams, such as, compression as free gas in the pore spaces, condensed as a solid or liquid, dissolved in the coal structure and adsorbed on the internal surface (Yee et al 1993). Recently, high-pressure adsorption isotherm experiments have been carried out to determine the adsorption capacity of various coals of different rank at variegated pressures (cf. Busch et al 2003, 2004, 2006). These experiments provide maximum adsorption capacities of coal, leading to determination of actual gas content of the coal seams.

The highly gaseous nature of the coal seams of Sawang Colliery, East Bokaro Coalfields stimulated us to carry out the present investigations. The actual gas adsorption capacity of coal seams from the study area is determined by conducting adsorption isotherm experiments on five coal samples under controlled $P-T$ conditions. Whereas, the total gas generated in these coal seams is estimated by following the empirical equations of Meisner (1984) and Kim (1977), these estimates are based on the proximate analyses of the coal samples, which are then compared with the actual gas content determined by the adsorption experiments.

\section{Geological framework}

The Bokaro Coalfield is situated in Hazaribagh and Giridih districts of Jharkhand state. This coalfield 
Table 1. Generalized stratigraphic succession of the East Bokaro Coalfield.

\begin{tabular}{|c|c|c|}
\hline Age & Formation & Lithology \\
\hline Lower Cretaceous & Intrusive & Lamprophyre and dolerite dykes and sills. \\
\hline Upper Triassic & Supra-Panchet & $\begin{array}{l}\text { Coarse-grained ferruginous sandstone, pebbly sandstone and red } \\
\text { clay }(600 \mathrm{~m}) \text {. }\end{array}$ \\
\hline Lower Triassic & Panchet & $\begin{array}{l}\text { Greenish micaceous sandstone, buff fine-grained sandstone, red } \\
\text { and green shale }(500-600 \mathrm{~m}) \text {. }\end{array}$ \\
\hline Upper Permian & Raniganj & $\begin{array}{l}\text { Medium-to-coarse grained calcareous, sandstone, fine-grained } \\
\text { greenish sandstone, grey shale, carbonaceous shale and thin coal } \\
\text { seams }(600 \mathrm{~m}) \text {. }\end{array}$ \\
\hline Middle Permian & Barren Measure & $\begin{array}{l}\text { Flaggy, fine-grained ferruginous sandstone micaceous sandy } \\
\text { shale and black shale with siderite band }(500 \mathrm{~m}) \text {. }\end{array}$ \\
\hline Lower Permian & Barakar & $\begin{array}{l}\text { Coarse-grained arkosic sandstone, fine-grained laminated sand- } \\
\text { stone, grey shale, carbonaceous shale and coal seams }(900 \mathrm{~m}) \text {. }\end{array}$ \\
\hline $\begin{array}{l}\text { Upper Carboniferous } \\
\text { to Lower Permian }\end{array}$ & Talchir & Tillite, greenish sandstones and needle shale. \\
\hline Pre-Cambrian & & Granite gneisses, amphibolites and Mica schist. \\
\hline
\end{tabular}

is a part of Damodar Valley Coalfield in eastern India, which is an important coal-producing area of the country. This coalfield has been divided into two distinct zones, viz., East Bokaro Coalfield (EBC) and West Bokaro Coalfield (WBC) by the Lugu hill massif (Dutt 1944-51; Kumar and Sahay 2001). The EBC is the eastern half of main Bokaro basin and exposes the complete sequence of Gondwana sediments, which occurs for more than $64 \mathrm{~km}$ along the $\mathrm{E}-\mathrm{W}$ profile and has a width of $12 \mathrm{~km}$ (Dutt 1944-51). This coalfield is traversed by a number of faults resulting in the formation of trough and horst structures (figure 1) (Dutt 1944-51; Mukhopadhyay 1984; Kumar and Sahay 2001).

The Sawang Colliery forms the northwestern part of the EBC and is spread over an area of $237 \mathrm{~km}^{2}$. Its geographical location is marked by latitude: $23^{\circ} 47^{\prime} 40^{\prime \prime} \mathrm{N}$ to $23^{\circ} 48^{\prime} 28^{\prime \prime} \mathrm{N}$ and longitude: $85^{\circ} 50^{\prime} 37^{\prime \prime} \mathrm{E}$ to $85^{\circ} 51^{\prime} 50^{\prime \prime} \mathrm{E}$ and included in Survey of India Toposheet No. 73 E/13 (figure 1) (Kumar and Sahay 2001; Pophare and Varade 2004a, 2004b). The coal-bearing sediments of Sawang area has unconformable contact with the underlying metamorphic rocks. The present study was concentrated on $1.4 \mathrm{~km}^{2}$ area in the Sawang south extension block. The coal seams are designated by the local name of places in the area such as Jarangdih, Kathara-Uchitdih, Kargali, Bermo and Karo groups of seams. The generalized stratigraphic succession of the East Bokaro Coalfields after Dutt (1944-51) and Raja Rao (1987) is shown in table 1.

\section{Coal seams of the study area}

There are totally twenty-six coal seams in the Sawang area; out of which eleven coal seams are in Karo area and three in Kargali and Bermo area (Kumar and Sahay 2001). In the present study totally five coal seams, viz., Jarangdih-IV, Jarangdih 6 feet, Jarangdih New, Karo-VIII and Bermo seams are investigated.

\subsection{Jarangdih-IV seam}

The Jarangdih-IV seam is the second coal seam of the Sawang south extension block. The depth of this seam is approximately 95 meters below the surface (mbs) with a thickness of 3.49 to $6.51 \mathrm{~m}$ (table 2). The top of Jarangdih-IV seam consists of alternate grey to black shale and sandstone sequences, whereas the bottom consists of fine-to-medium grained sandstone and alternate sequences of sandy shale to grey shale.

\subsection{Jarangdih new seam (Jarangdih-III)}

The Jarangdih new seam occurs below Jarangdih-IV seam. This seam is approximately $65 \mathrm{mbs}$, with the thickness of 2.09 to $4.74 \mathrm{~m}$ (table 2). The top of the Jarangdih new seam consists of carbonaceous shale to grey shale and alternate shale-sandstone sequences, while the bottom consists of alternate sequences of sandy to grey shale. 
Table 2. Details of coal samples studied.

\begin{tabular}{|c|c|c|c|c|c|}
\hline $\begin{array}{l}\text { Sample } \\
\text { no. }\end{array}$ & $\begin{array}{l}\text { Name of the } \\
\text { seam }\end{array}$ & $\begin{array}{l}\text { Depth } \\
(\mathrm{mbs})^{*}\end{array}$ & $\begin{array}{l}\text { Thickness } \\
\text { (m) }\end{array}$ & $\begin{array}{l}\text { Type of } \\
\text { mining }\end{array}$ & $\begin{array}{c}\text { Type of coal } \\
\text { sample collected }\end{array}$ \\
\hline CG-81 & Jarangdih 6 feet & 117 & $\sim 2 \mathrm{~m}$ ( 6 feet $)$ & \multirow{3}{*}{ Under ground } & Channel \\
\hline CG-85 & Jarangdih new & 65 & $2.09-4.74$ & & Channel \\
\hline CG-97 & Jarangdih-IV & 95 & $3.49-6.51$ & & Channel \\
\hline CG-119 & Karo-VIII & 25 & $20-64$ & \multirow{2}{*}{ Open pit } & Channel \\
\hline CG-121 & Bermo & 32 & $15-17$ & & Channel \\
\hline
\end{tabular}

${ }^{*}$ mbs - meters below surface.

\subsection{Jarangdih 6 feet seam (Jarangdih-II)}

The Jarangdih 6 feet seam occurs below Jarangdih new seam. The approximate depth of this seam is $117 \mathrm{mbs}$, with a thickness of 1.37 to $2.55 \mathrm{~m}$ (table 2). However, the normal thickness of this seam in the study area is less than $2 \mathrm{~m}$ (approx. 6 feet), hence it is termed as Jarangdih 6 feet seam. The top of Jarangdih 6 feet seam encompasses sandy shale with occasional alternate sequences of fine-to-medium grained sandstone and shale, whereas bottom of the seam is mostly composed of alternate sequences of shale and fine-medium grained sandstone with occasional occurrence of sandy shale to carbonaceous shale layers.

\subsection{Karo-VIII seam}

The Karo group comprises of eleven coal seams, which are developed towards the basal part of the Barakar Formation. These seams are designated from top to bottom as Karo-XI to Karo-I (down the strata). Out of these eleven coal seams, Karo-X is known as Karo Upper Major and Karo-VIII is known as Karo Lower Major. The Karo-X seam has a thickness of 8.5 to $16 \mathrm{~m}$, whereas Karo-VIII seam has a thickness of 20 to $64 \mathrm{~m}$ and occurs at a depth of $25 \mathrm{mbs}$ (table 2). The coal samples from the Karo-VIII seam are studied in the present work.

\subsection{Bermo seam}

The Bermo seam is one of the important and thick seams of the East Bokaro Coalfield. In the study area, the outcrop of Bermo seam can be traced for approximately one $\mathrm{km}$ along the Konar River on $\mathrm{E}-\mathrm{W}$ profile. Towards the west it is disrupted successively by normal and oblique faults. The Bermo seam has a thickness of 15 to $17 \mathrm{~m}$ and occurs at a depth of $32 \mathrm{mbs}$ (table 2) (Pophare and Varade 2004b).

\section{Methodology}

Totally twenty coal samples were collected from the five coal seams, viz., Jarangdih-IV, Jarangdih
Table 3. Maceral content of the coal samples.

\begin{tabular}{lccccc}
\hline $\begin{array}{l}\text { Sample } \\
\text { no. }\end{array}$ & $\begin{array}{c}\text { Vitrinite } \\
(\%)\end{array}$ & $\begin{array}{c}\text { Inertinite } \\
(\%)\end{array}$ & $\begin{array}{c}\text { Liptinite } \\
(\%)\end{array}$ & $\begin{array}{c}\text { Mineral } \\
\text { matter }\end{array}$ & $\begin{array}{c}\text { Ro Calc. } \\
(\%)\end{array}$ \\
\hline CG-81 & 69.02 & 30.32 & 0.66 & 10.56 & 1.15 \\
CG-85 & 65.75 & 31.16 & 3.09 & 11.75 & 1.18 \\
CG-97 & 83.15 & 14.93 & 1.94 & 17.70 & 0.94 \\
CG-119 & 62.50 & 36.81 & 0.69 & 14.62 & 1.21 \\
CG-121 & 71.70 & 27.61 & 0.69 & 10.97 & 1.11 \\
\hline
\end{tabular}

Ro Calc. \% - Vitrinite reflectance, calculated.

new, Jarangdih 6 feet, Karo-VIII and Bermo seams from underground as well as open cast mines of the Sawang Colliery of EBC. In the present work, three samples from Jarangdih group of underground coal seams and one sample each from Bermo and Karo group of surface to subsurface seams were studied. The location of samples, name of the seams, type of coal samples collected, depth and thickness of coal seams are given in table 2 .

Under megascopic studies, different physical properties and lithotype of coal samples are studied. The coal samples are black to brownish black in colour, moderately hard, show vitreous to subvitreous lustre, sub-conchoidal to uneven fracture with medium to high specific gravity. Vitrain and clarain are the dominant lithotypes in these samples. Various cleat characteristics including cleat intensity and cleat density confined within different litho types were studied on $5 \times 5 \mathrm{~cm}$ block of coal samples. Polished blocks and pellets of coal samples were analysed for maceral group identification and determination of maceral composition along with micropores and cleat aperture distribution (Pophare and Varade 2004a, 2006). These studies were carried out by following the standard ICCP procedure (ICCP 1971) on the Leitz MPV-2 reflectance microscope, with fluorescence attachment, at the Coal Petrology Laboratory of Indian School of Mines (ISM), Dhanbad (table 3).

The coal samples were split and subjected to proximate analysis, actual gas adsorption isotherm studies and detailed petrography. The ash, moisture, volatile matter and fixed carbon 
Table 4. Proximate analysis of the coal samples, estimated methane gas and Langmuir parameters.

\begin{tabular}{lccccccccc}
\hline $\begin{array}{l}\text { Sample } \\
\text { no. }\end{array}$ & M & VM (daf) & Ash & FC & $\begin{array}{c}\text { Fuel } \\
\text { ratio }\end{array}$ & A & B & P $_{\mathrm{L}}$ & V $_{\mathrm{L}}$ \\
\hline CG-81 & 2.98 & 28.31 & 12.78 & 55.93 & 1.97 & 40.87 & 17.00 & 2.86 & 24.94 \\
CG-85 & 2.01 & 27.72 & 19.67 & 50.60 & 1.82 & 43.85 & 16.50 & 3.75 & 26.88 \\
CG-97 & 2.61 & 33.86 & 10.92 & 52.61 & 1.55 & 15.56 & 16.10 & 2.49 & 22.99 \\
CG-119 & 1.45 & 27.01 & 30.01 & 41.53 & 1.53 & 47.52 & 15.80 & 2.92 & 22.94 \\
CG-121 & 1.28 & 29.34 & 18.26 & 51.12 & 1.74 & 35.82 & 16.10 & 2.70 & 23.36 \\
\hline
\end{tabular}

All the samples are strongly caking and forms coke button. $\mathbf{M}$ - moisture content (\%), VM-volatile matter (\%), FC - fixed carbon (\%), daf - dry and ash free basis, $\mathbf{A}$ - estimated volume of methane generated $\left(\mathrm{m}^{3} / t\right)$ as per Meisner (1984), B - actual volume of adsorbed gas (Std. $\mathrm{m}^{3} / \mathrm{t}$, daf) during adsorption experiment, $\mathbf{P}_{\mathbf{L}}-$ Langmuir pressure $(\mathrm{MPa})$, and $\mathbf{V}_{\mathbf{L}}-$ Langmuir volume $\left(\mathrm{Std} . \mathrm{m}^{3} / \mathrm{t}\right.$, daf).

Table 5. Parameters for estimation of methane gas by Kim's empirical equation.

\begin{tabular}{lccccccr}
\hline $\begin{array}{l}\text { Sample } \\
\text { no. }\end{array}$ & $V_{w} / V_{d}$ & $K$ & $N$ & $b$ & $T\left({ }^{\circ} \mathrm{C}\right)$ & $\begin{array}{c}\text { Pressure } \\
(\text { atm })\end{array}$ & $\begin{array}{c}V \\
\left(\mathrm{~m}^{3} / \mathrm{t}\right)\end{array}$ \\
\hline CG-81 & 0.57 & 7.18 & 0.30 & 0.17 & 33 & 11.23 & 4.43 \\
CG-85 & 0.66 & 7.06 & 0.30 & 0.21 & 32 & 6.24 & 2.84 \\
CG-97 & 0.60 & 6.84 & 0.30 & 0.21 & 32 & 9.12 & 3.40 \\
CG-119 & 0.73 & 6.83 & 0.30 & 0.21 & 31 & 2.40 & 1.19 \\
CG-121 & 0.75 & 6.99 & 0.30 & 0.21 & 31 & 3.07 & 2.00 \\
\hline
\end{tabular}

contents were determined at the Fuel Engineering Laboratory of Indian School of Mines, Dhanbad (table 4).

The vitrinite reflectance (Ro\%) is calculated by using the formula given by Rice (1993), which is as follows:

$$
\text { Ro\% }=-2.712 \times \log (\mathrm{VM})+5.092 .
$$

The Ro\% (calculated) values range from $0.94 \%$ (CG-97) to $1.21 \%$ (CG-119) (table 3). The applicability of this formula is restricted to the particular range of VM, i.e., $15 \%<\mathrm{VM}<40 \%$ (Rice 1993). The VM\% of the coal samples of Sawang Colliery are within this limit (tables 3 and 4 ).

\subsection{Estimation of methane content}

The generation of methane gas depends on the temperature, pressure and composition of coal seams. Generally, with increasing depth and $P-T$ conditions, enhancement in the rank and maturity of the coal is observed along with increase in carbon percentage. Proximate analysis of coal helps to determine its rank and maturity. The CBM assessment of an area is primarily based on the above parameters. Several workers gave empirical formulae for the estimation of CBM in the coal seams depending on various parameters. Meisner (1984) observed that the amount of methane gas $\left(\mathrm{V}_{\mathrm{CH}_{4}}\right)$ is related to volatile matter, calculated on dry ash free basis, by the following equation:

$$
\mathrm{V}_{\mathrm{CH}_{4}}=-325.6 \times \log \left(\frac{\mathrm{VM}}{37.8}\right) .
$$

The values of the amount of gas generated are given in table 4.

Most of the gas in coal is adsorbed on the internal surface of micropores and varies directly with pressure and inversely with temperature. The relationship between the volume of adsorbed gas with pressure and temperature based on the moisture and ash content of coal samples was estimated by Kim's empirical equation (Kim 1977), (table 5) which is as follows:

$$
V=\left[\frac{(100-M-A)}{100}\right] \times V_{w} / V_{d}\left[K(P)^{\mathrm{N}}-b \times T\right],
$$

where, $V=$ Volume of methane gas adsorbed (cc/g), $M=$ Moisture content (\%); $A=$ Ash content $(\%)$.

$$
V_{w} / V_{d}=\frac{1}{(0.25 \times M \times 1)}
$$

where $V_{w}=$ Volume of gas adsorbed on wet coal (cc/g) and, $V_{d}=$ Volume of gas adsorbed on dry coal (cc/g). 


$$
K=0.8\left(\frac{\mathrm{FC}}{\mathrm{VM}}\right)+5.6
$$

where $\mathrm{FC}=$ Fixed carbon $(\%) ; \mathrm{VM}=$ Volatile matter (\%); $N=$ Constant, depends on the composition of coal (for most bituminous coals, $N=0.390 .013 \times K) ;$ and $b=$ Adsorption constant due to temperature change $\left(\mathrm{cc} / \mathrm{g} /{ }^{\circ} \mathrm{C}\right)$.

$$
T=2.5 \times \frac{h}{100}+T_{0}
$$

where $T=$ Temperature at given depth; $T_{0}=$ ground temperature; $h=\operatorname{depth}(\mathrm{m})$ (temperature gradient for Sawang area of $\mathrm{EBC}$ is $2.5^{\circ} \mathrm{C} / 100 \mathrm{~m}$ ); and $P=$ pressure $(\mathrm{atm})\left[\left(\mathrm{P}_{\text {hyd }}\right)=0.096 \times \mathrm{h}\right]$.

\section{Adsorption isotherm studies}

Adsorption is a reversible physical process, controlled by Vander Wall forces between the gas molecules. With increase in temperature and decrease in pressure the gas desorbs, whereas increase in pressure and decrease in temperature leads to increased adsorption on the internal surface of coal. The amount of gas adsorbed depends on the following factors:

- Nature of coal (adsorbent).

- Nature of gas (adsorbate) e.g., $\mathrm{CH}_{4}, \mathrm{CO}_{2}$ and other gases.

- Total surface area of pores and cleats available (micro porosity of adsorbent).

- Pressure and critical temperature of adsorbate and adsorbent.

- Moisture, ash content and oxidation state of coal.

Adsorption of gas in the coal seams takes place by two modes. Initially, the gas gets adsorbed on the pores and cracks of the surface and subsequently penetrates and accumulates within the internal structure of coal. The flow rate of gas is determined by the pressure difference, $P_{\text {rock }}-P_{\text {wellbore}}$, whereby $P_{\text {rock }}$ usually equals the hydrostatic pressure (if no overpressure). The adsorption isotherm experiment reveals maximum methane gas adsorption capacities of coal samples, at variable pressures under constant temperature.

\subsection{Experimental setup}

The adsorption experiment was carried out at Central Mining and Fuel Research Institute (CMFRI), Dhanbad, on crushed coal sample particles that pass through a 60 mesh screen. The moisture and ash content was obtained by proximate analyses of the original coal sample to correct the adsorption data to a standard dry and ash free basis. The instrument details and the analytical procedures were given by Beamish and Crosdale (1995); Crosdale et al (1998); Mazumdar and Varma (1999); Varma and Mazumdar (2001).

The experimental setup of adsorption isotherm consists of water bath, control panel, sample cells, reference cells and vacuum pumps. The water bath was used to maintain isothermal conditions. The control panel regulates flow of gas to the sample and reference cells and monitors gas pressure. The determination of the isotherm involves determination of dead/void volume and determination of adsorption isotherm.

The sample cell was filled with $100 \mathrm{~g}$ of coal sample and attached to the main apparatus. This cell was initially kept at atmospheric pressure. The dead volume of the apparatus was determined by evacuation and then filling the reference cell with helium and allowing it to equilibrate. The helium gas was then admitted into the sample cell and the dead volume was calculated by the drop in pressure between the sample cell and reference cell.

After determination of dead volume, the apparatus was again evacuated for determination of adsorption isotherm. Subsequently, methane gas was added to the reference cell, allowed to equilibrate and then admitted into the sample cell by positive displacement mercury pump. The experiment was run by injecting additional volume of methane gas at progressively increasing pressure ranging from atmospheric pressure to pressure exceeding initial reservoir pressure. The initial and final pressures of both the cells were noted (table 6). The amount of gas adsorbed by the coal sample was measured by the drop in pressure during pressure equilibration, which occurs after each pressure increase. The experimental temperature was kept constant at $30^{\circ} \mathrm{C}$ (table 6 ).

Results of the adsorption isotherm studies, input pressure and output adsorbed gas content of individual coal samples are given in table 7 . The methane adsorption isotherms at standard experimental $P-T$ conditions, for the individual coal samples (on dry and ash free basis, daf), against variable pressure are shown in figure 2 . It is seen that the gas adsorption capacity of coal samples increases with increasing pressure. The maximum amount of methane gas adsorbed is observed in sample CG- $81\left(V=17 \mathrm{~m}^{3} / \mathrm{t}\right.$, daf, at a pressure of $5.95 \mathrm{MPa}$ ) and the minimum amount of gas adsorbed is found in sample CG-119 $\left(V=15.80 \mathrm{~m}^{3} / \mathrm{t}\right.$, daf, at a pressure of $5.53 \mathrm{MPa}$; table 7). 

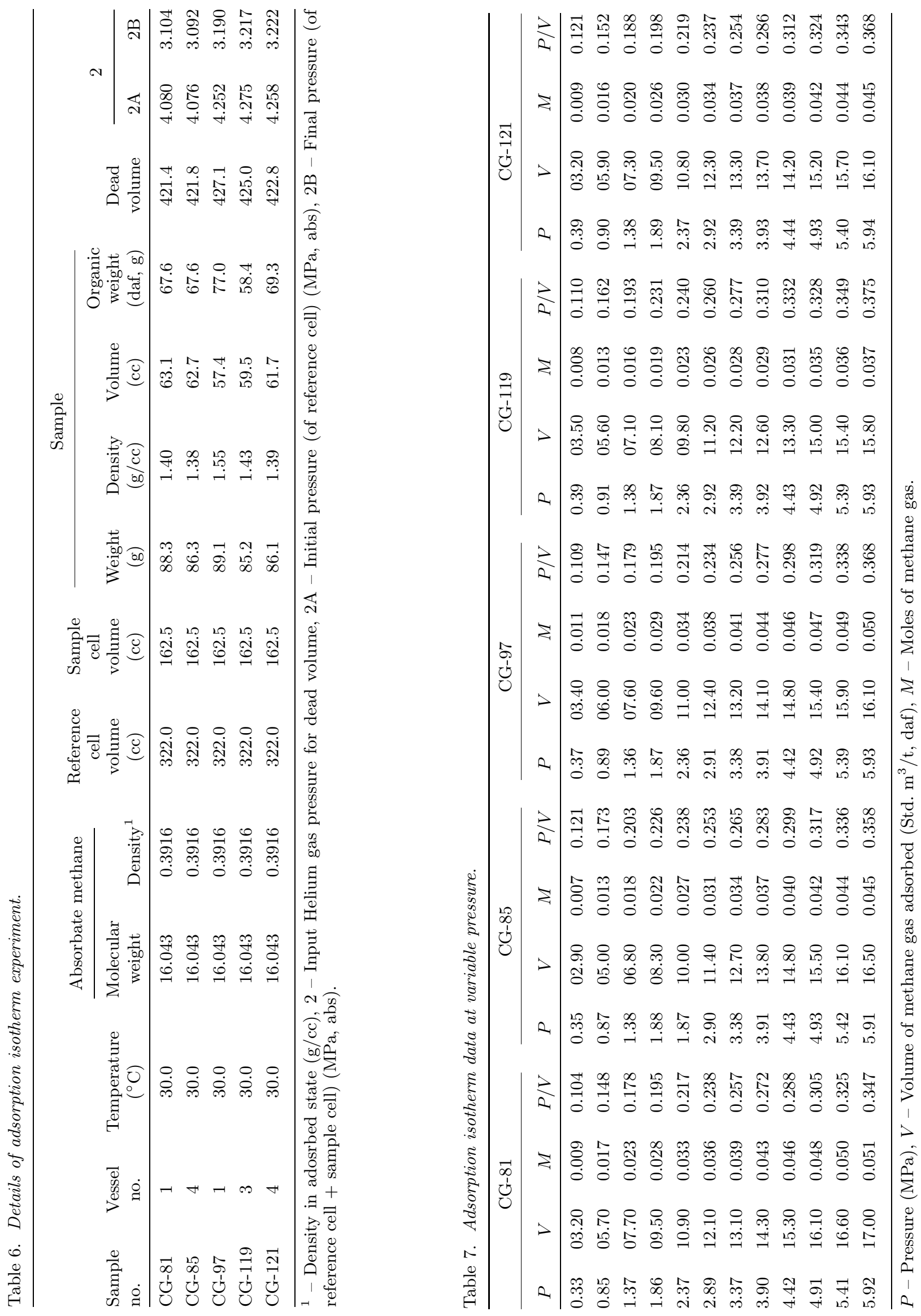

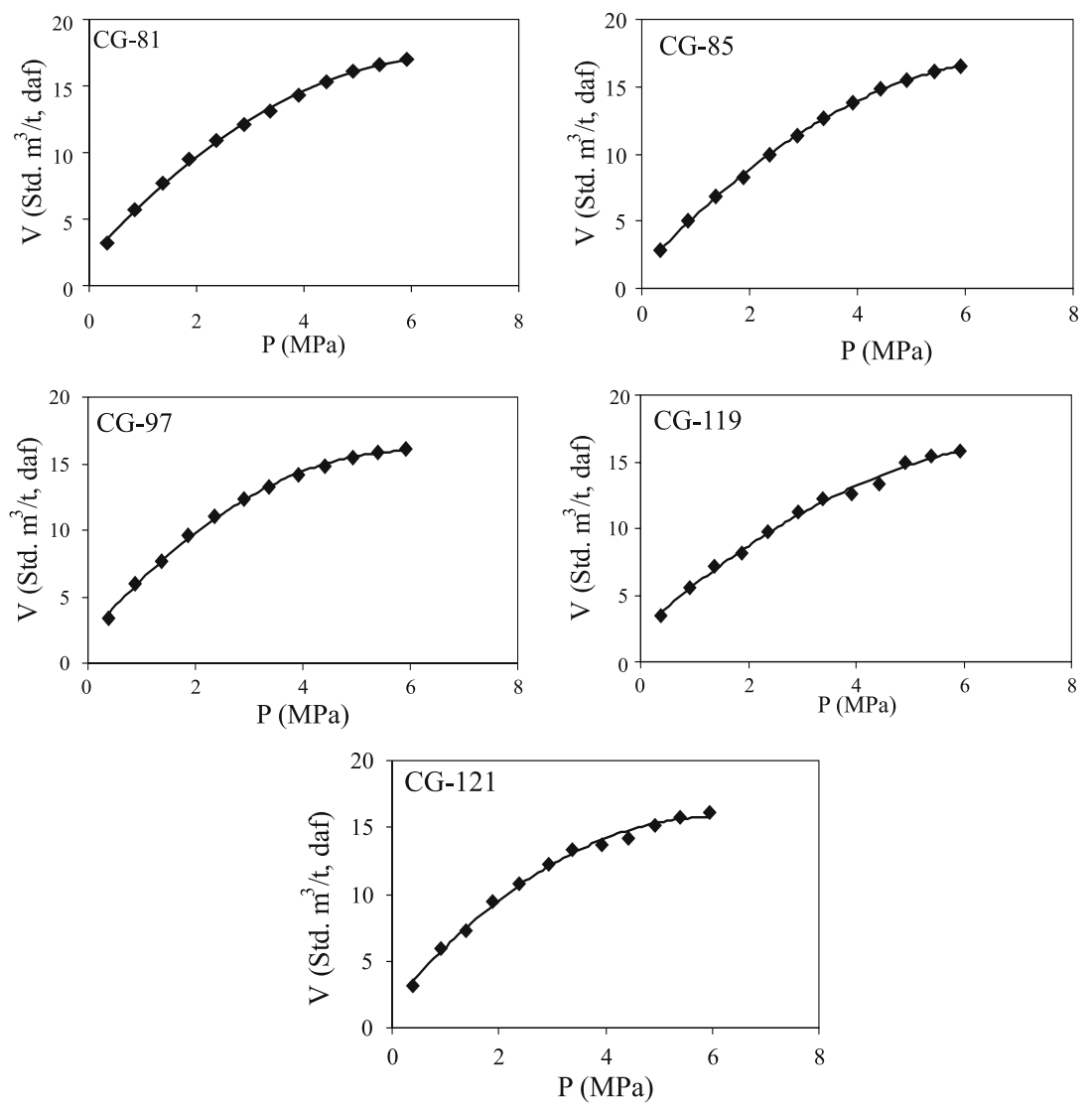

Figure 2. Methane gas adsorption isotherm at variable pressure for five coal samples.

\subsection{Parameterisation of adsorption data}

The experimental methane sorption data are parameterised in terms of Langmuir sorption isotherm function. The Langmuir equation is expressed as:

$$
V=\mathrm{V}_{\mathrm{L}} \frac{P}{\left(\mathrm{P}_{\mathrm{L}}+P\right)}
$$

where, $V=$ Volume of gas adsorbed (Std. $\mathrm{m}^{3} / \mathrm{t}$, daf), $P=$ Equilibrium pressure $(\mathrm{MPa}), \mathrm{V}_{\mathrm{L}}=$ Langmuir volume (Std. $\mathrm{m}^{3} / \mathrm{t}$, daf), and $\mathrm{P}_{\mathrm{L}}=$ Langmuir pressure $(\mathrm{MPa})$.

The Langmuir model is valid for monolayer adsorption at low pressures (Langmuir 1918), however it is found to be applicable for methane adsorption data on coal at intermediate and high pressure with sufficient degree of precision and the Langmuir equation fits this data (cf. Busch et al 2003, 2004, 2006). The Langmuir parameters were determined individually by best fit regression for five adsorption datasets. These parameters when plotted against VM, maceral content and vitrinite reflectance (Ro\% calc.), which show poor correlations (figures 3 and 4 ). The maximum methane sorption capacity, i.e., $\mathrm{V}_{\mathrm{L}}$ is observed in sample CG-85 $\left(\mathrm{V}_{\mathrm{L}}=26.88 \mathrm{Std} . \mathrm{m}^{3} / \mathrm{t}\right.$, daf and
$\left.\mathrm{P}_{\mathrm{L}}=3.75 \mathrm{MPa}\right)$ and minimum in CG-119 $\left(\mathrm{V}_{\mathrm{L}}=22.94\right.$ Std. $\mathrm{m}^{3} / \mathrm{t}$, daf and $\left.\mathrm{P}_{\mathrm{L}}=2.92 \mathrm{MPa}\right)$.

\section{Results and discussion}

The CBM potential of the coal seams of Sawang area was evaluated on the basis of petrographic studies of different maceral groups and adsorption isotherm studies. The pore structure analysis of these litho types shows greater pore volumes for dull coals compared to their equivalent bright coal pairs. In contrast, bright coals have larger surface area. These contrasting trends suggest that the bright coals are more highly micro-porous compared to dull pairs (cf. Crosdale and Beamish 1995). The vitrinite maceral contains micro pores and shows higher gas adsorption capacity in pores of $<2 \mathrm{~mm}$ size, whereas the inertinite maceral shows less gas adsorption capacity in pores of $2-5 \mu \mathrm{m}$ sizes (Pophare and Varade 2004a, 2006). Moreover, the well-developed cleat attributes of varying sizes in the investigated coal seams of Sawang area have excellent methane gas adsorption capacity (Pophare and Varade 2004a, 2006).

The coal seams of Sawang area show depthwise increase in rank and maturity, which is reflected by increase in their fuel ratio and fixed carbon 

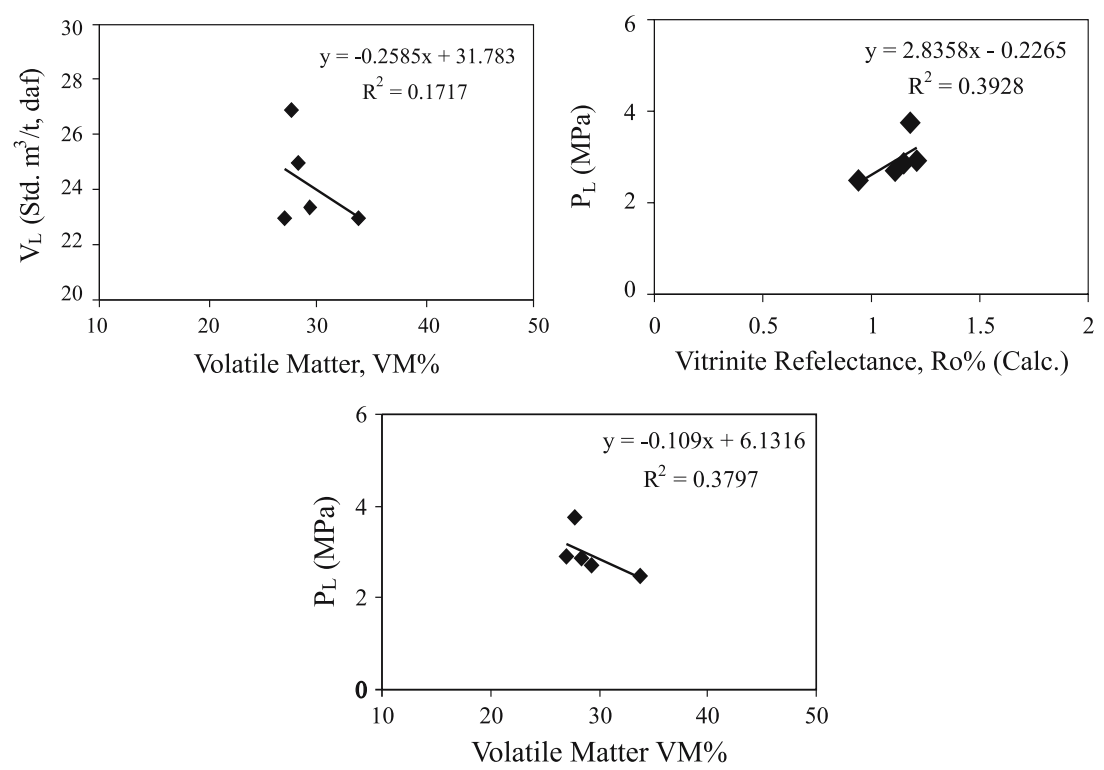

Figure 3. Variation of Langmuir parameters with VM and vitrinite reflectance (Ro\% calc.).
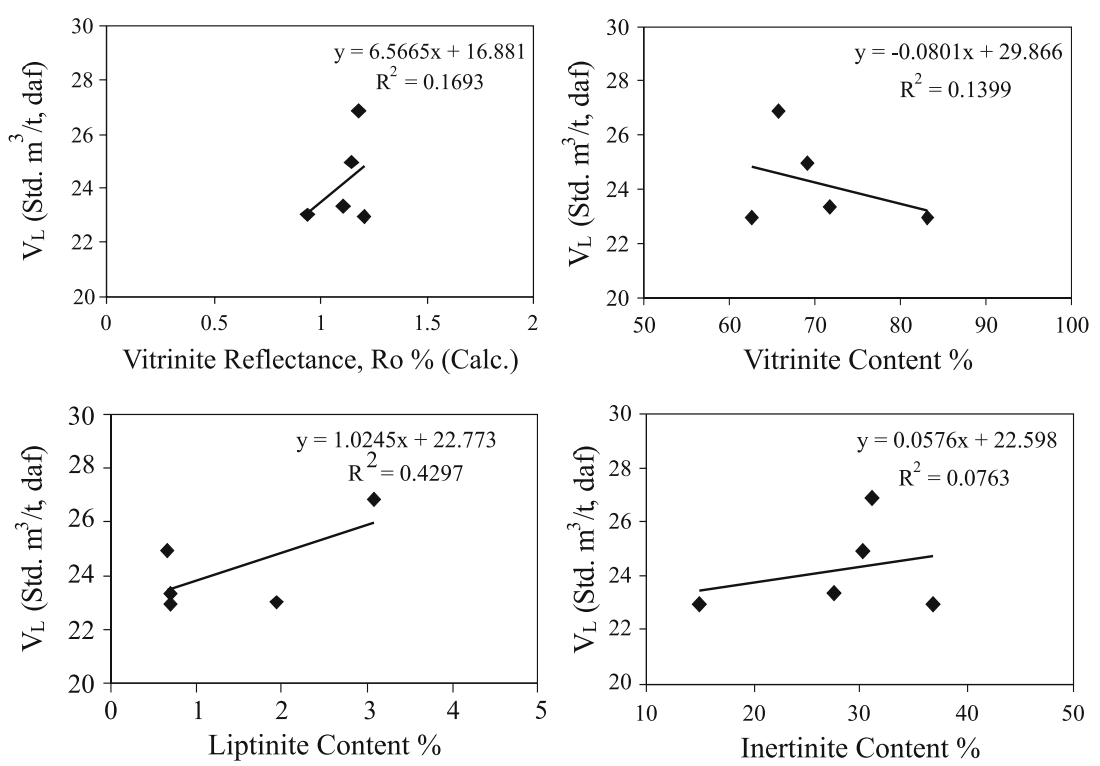

Figure 4. Variation of Langmuir parameter $\mathrm{V}_{\mathrm{L}}$ with different maceral content and vitrinite reflectance (Ro\% calc.).

content (Sharma and Ram 1966; Chandra 2000; Pophare and Varade 2004b). The coal sample CG81 (depth: $117 \mathrm{mbs}$ ) shows highest fixed carbon content $(55.93 \%$, daf) and fuel ratio (1.97), indicating its high rank and maturity (table 4); whereas, sample CG-119 (depth: $25 \mathrm{mbs}$ ) shows minimum fixed carbon content $(41.53 \%$, daf) and fuel ratio (1.53) (table 4), indicating low rank and less maturity of this sample. The deeper seams have low ash content and high gas adsorption capacity, which increases with enrichment of carbon content in the coal seams of Sawang area (Pophare and Varade 2006).
The $V_{\mathrm{CH}_{4}}$ estimates of the total amount of methane generated, calculated by using Meissner's equation varies from $47.52 \mathrm{~m}^{3} / \mathrm{t}$ (CG-119) to $15.56 \mathrm{~m}^{3} / \mathrm{t}$ (CG-97) (table 4); whereas, the actual gas adsorbed in the coal samples on the dry ash free basis ranges from $15.80 \mathrm{~m}^{3} / \mathrm{t}$ (CG-119) to $17.00 \mathrm{~m}^{3} / \mathrm{t}$ (CG-81) (table 4). The present depth of occurrence of Karo-VIII seam (CG-119) is 25 mbs. The Jarangdih coal seam (CG-81) shows generation of $40.87 \mathrm{~m}^{3} / \mathrm{t}$ of methane gas and maximum gas adsorption capacity. The depth of this seam (117 mbs) corroborates these observations (tables 2 and 4). 

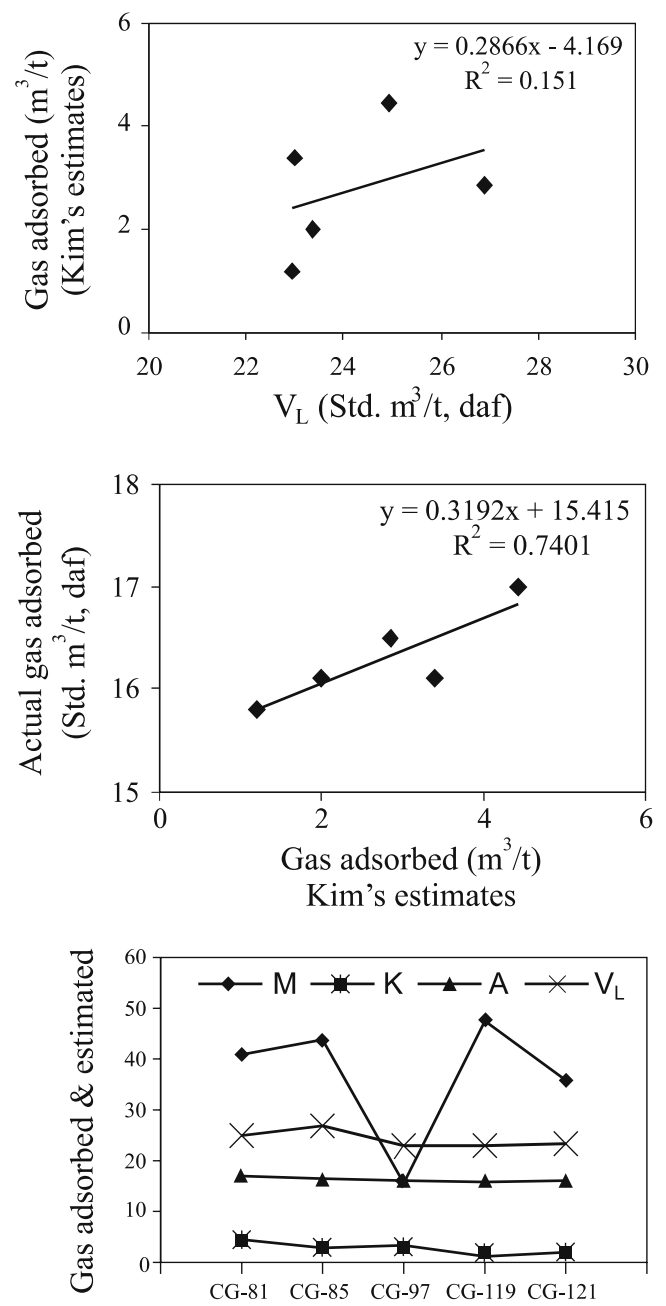

Sample number

Figure 5. Comparison of $\mathrm{V}_{\mathrm{L}}$, methane gas estimated by Meissner's equation (M), gas adsorbed by Kim's estimates $(K)$ and actual gas adsorbed (A. experimental).

The methane gas content estimated by the Kim's empirical equation varies from $4.43 \mathrm{~m}^{3} / \mathrm{t}$ (CG-81) to $1.19 \mathrm{~m}^{3} / \mathrm{t}$ (CG-119) (table 5). This estimated methane content differs from those determined from the adsorption isotherm experiments. The Kim's empirical estimates of methane gas content are determined at hydrostatic pressure and existing geothermal gradient in the Sawang area, which has an average value of $2.5^{\circ} \mathrm{C} / 100 \mathrm{~m}$. Moreover, the accuracy of estimated gas content depends on how closely the pressure gradient approaches the normal value of $0.096 \mathrm{~atm} / \mathrm{m}$ (Kim 1977). The low estimates of methane gas content of the coal seams of Sawang area is due to the low values of pressure.

The difference in maximum sorption capacities of the investigated coal samples may be attributed to variation in pressure and difference in maceral composition. The coal seams of the study area are dominated by the vitrinite group of macerals. The bituminous coal sample CG-85 has the highest liptinite maceral and moderate vitrinite and inertinite contents with comparable vitrinite reflectance value $($ Ro\% $=1.18)$, along with maximum value of $\mathrm{V}_{\mathrm{L}}$ compared to the samples with similar maturity (tables 3 and 4). The sample CG-119 has lowest vitrinite and liptinite maceral contents and highest inertinite content with highest vitrinite reflectance value $(\mathrm{Ro} \%=1.21)$, but minimum value of $\mathrm{V}_{\mathrm{L}}$. Whereas, the sample CG- 81 has Ro\% $=1.15$ and moderate contents of vitrinite, inertinite and liptinite macerals and moderate $\mathrm{V}_{\mathrm{L}}=24.94 \mathrm{Std} . \mathrm{m}^{3} / \mathrm{t}$, daf (tables 3 and 4). This maceral group does not show any correlation with the Langmuir parameter $\mathrm{V}_{\mathrm{L}}$ (figure 4 ). This signifies that there is no relation between the gas adsorption capacity and maceral composition of the coal samples of the Sawang area (cf. Faiz et al 1992; Laxminarayana and Crosdale 1999). This is in conformation with the investigations carried out on Indian coals by Laxminarayana and Crosdale (2002), which have shown that the vitrinite maceral content does not influence methane sorption capacities. Moreover, the maceral composition is pre-determined by the depositional conditions of the coal and therefore invariant in further evolution of the coal seam. Hence, in the coal seams of Sawang Colliery, the influence of maceral composition on adsorption capacity remains ambiguous.

The comparison of results of actual adsorption isotherm with the estimates of gas adsorbed by Kim's empirical equation shows positive correlation, but the Langmuir parameter $\mathrm{V}_{\mathrm{L}}$ does not show any correlation (figure 5). This suggests that the assessment for CBM potential of coal seams in the Sawang area obtained by these two independent methods show coherence.

\section{Conclusions}

It is clear that the amount of methane generated in the coal seams of Sawang Colliery is higher than the amount of methane gas present. This is also verified by the adsorption isotherm studies. Although, a major proportion of the gas is stored by adsorption, a remarkable portion of the gas escapes into the surroundings. This migration may occur due to limited storage capacity of coal seams and excess production of methane gas. The coal seams are saturated with respect to their adsorption capacity. The deeper coal seams hold higher quantity of methane gas compared to shallow coal seams as the amount of gas generated and the storage capacity is directly proportional to the depth of coal seams. This variation in the amount of CBM generated and the amount of gas present can be attributed to several factors such as release 
of CBM due to pressure release, hydrological condition, dewatering and variegated tectonic disturbances/upliftment history of the Jharia basin in general and Sawang Colliery area of East Bokaro Coalfield in particular.

\section{Acknowledgements}

Authors are thankful to Dr. Atul Varma, Associate Professor, ISM, Dhanbad, Prakash Singh, Research Scholar ISM, Dhanbad and Dr. A K Singh, Scientist, CMRI, Dhanbad, for providing analytical help and necessary suggestions. Thanks are also due to an anonymous reviewer for meticulous review and constructive comments, which helped in improving the manuscript.

\section{References}

Acharyya S K 2000 Coal and lignite resources of India - An overview; J. Geol. Soc. India 57 41-43.

Acharyya S K 2001 Indian coal basins as a source of coal bed methane - prospects and retrospects; In: Proc. Int. Seminar on "Coal Bed Methane-Prospects and Potentialities", South Asian Asso. Eco. Geologist 1-13.

Beamish B B and Crosdale P J 1995 The influence of maceral content on the sorption of gases by coal and the association with overbursting; In: Lama R D (ed.), "Management and Control of High Gas Emission and Outburst in Underground Coal Mines", Proc. Int. sympcum-workshop, Wollongong. Kiama, NSW, Australia 353-362.

Biswas S K 1995 Prospects of coal bed methane in India; Indian J. Petroleum Geol. 4(2)1-23.

Busch A, Gensterblum Y and Krooss B M 2003 Methane and $\mathrm{CO}_{2}$ sorption and desorption measurements on dry Argonne premium coals: pure components and mixtures; Int. J. Coal Geology 55 205-224.

Busch A, Gensterblum Y, Krooss B M and Littke R 2004 Methane and Carbon Dioxide Adsorption/Diffusion Experiments on Coal: An Upscaling and Modelling Approach. Int. J. Coal Geology 60 151-168.

Busch A, Gensterblum Y, Krooss B M and Siemons N 2006 Investigation of high-pressure selective adsorption/desorption behaviour of $\mathrm{CO}_{2}$ and $\mathrm{CH}_{4}$ on coals: an experimental study; Int. J. Coal Geology 66 53-68.

Chandra D 2000 A textbook of coal (Indian context), $1^{\text {st }}$ edn., Tara book agency, Varanasi, 280-281.

Crosdale P J, Beamish B and Valix M 1998 Coalbed methane sorption related to coal composition; In: "Coalbed methane: from coalmine outbursts to a gas resource" (ed.) Flores R M, Int. J. Coal Geology 35 $147-158$

Crosdale P J and Beamish B 1995 Methane diffusivity at South Bulli (NSW) and Central (Old) collieries in relation to coal maceral composition; In: "Management and Control of High Gas Emission and Outburst in Underground Coal Mines" (ed.) Lama R D, Proc. Int. sympcum-workshop, Wollongong. Kiama, NSW, Australia 363-367.

Das Gupta S C 2006 A prospective of exploration and resource evaluation of coal bed methane (CBM) in India vis-à-vis the role of the Geological Survey of India; J. App. Geochem. 8(2A) 359-365.
Dutt A B 1944-51 East Bokaro Coalfields; In: Raja Rao C S 1987 "Coalfields of India", Bull. Geol. Surv. India A IV, 45(I) $1-9$.

Dutt A B 2007 Strategies for regional exploration of solid fossil fuels and CBM-A futuristic outlook, Gond. Geol. Magz. Spl. Vol. 9 81-86.

Dutt A B, Mukhopadhyay A and Chakrabati N C 2001 Coal bed methane potential in Central Indian coalfieldspossibilities and prospect; In: Proc. Int. Seminar on "Coal Bed Methane-Prospects and Potentialities", South Asian Asso. Eco. Geologist 26-36.

Faiz M M, Aziz N I, Hutton A C and Jones B G 1992 Porosity and gas sorption capacity of some eastern Australian coals in relation to coal rank and composition; In: Proc. Symp. on "Coal Bed Methane Resource Develop.", Australia 4 9-20.

Higgs M D 1986 Laboratory studies into the generation of natural gas from Coals; In: Habitat of Paleozoic gas in N.W. Europe, Brooks J, Goff J C and Van Hoorn B (eds) Geol. Soc. Spl. Publ. 23 113-120.

ICCP 1971 International committee for coal petrology, Inter. hand-book of coal petrography; $C N R S$, Paris, $2^{\text {nd }}$ edn, $184 \mathrm{p}$

Kim G A 1977 Estimating methane content of bituminous coal beds from adsorption data; U.S. Bureau of Mines RI8245 1-22.

Kumar U and Sahay A V 2001 Prospects of coal bed methane in Jarangdih-Asnapani Graben, East Bokaro Coalfields, Bihar, India; In: Proc. Int. Seminar on "Coal Bed Methane-Prospects and Potentialities", South Asian Asso. Eco. Geologist 49-56.

Langmuir I 1918 The adsorption of gases on plane surfaces of glass, mica and platinum; J. American Chem. Soc. 40 1361.

Laxminarayana C and Crosdale P J 1999 Role of coal type and rank on methane sorption characteristics of Bowen basin, Australia coals; Int. J. Coal Geology $\mathbf{4 0}$ 309-325.

Laxminarayana C and Crosdale P J 2002 Controls on methane sorption capacity of Indian coals; $A A P G$ Bulletin 86 201-212.

Levine J R 1987 Influence of coal composition on the generation and retention of coal bed natural gas: Tuscaloosa, Alabama; In: Proc. Coal bed Methane Symp. Paper $\mathbf{8 7 1 1}$ $15-18$.

Levine J R 1991a New methods for assessing gas resources in thin-bedded, high-ash coals: Tuscaloosa, Alabama; In: Proc. Coal bed Methane Symp. Paper $\mathbf{9 1 2 5}$ 115-125.

Levine J R 1991b The impact of oil formed during coalification on generation and storage of natural gas in coal bed reservoir systems: Tuscaloosa, Alabama; In: Proc. Coal bed Methane Symp. Paper 9126 307-315.

Levine J R 1992 Influences of coal composition on coal seam reservoir quality: a review; In: Proc. Int. Symp. "Coal Bed Methane Resource Develop." Townsville 1 1-28.

Mazumdar S and Varma A K 1999 Sorption isotherm for coal bed methane exploration - a case study from Jharia coal basin, India; In: "Mine Environment and Ventilation" (ed.) Panigrahi D C, Oxford-IBH Publ. Co., $145-149$.

Meisner R F 1984 Cretaceous and Lower tertiary coal as sources for gas accumulations in rocky mountain area; In: "Source rocks of rocky mountain region" (eds) Woodward J, Meisner F F and Clayton J L, Rocky Mountain Asso. Geologists Guide Book, 401-431.

Mukhopadhyay A 1984 Inter-relationship of tectonism and sedimentation in the Jharia basin; J. Geol. Soc. India 25(7) 445-455. 
Narasimhan K S, Mukherjee A K, Sengupta S, Singh S M and Alam M M 1998 Coal bed methane potential in India; Fuel 77(15) 1865-1866.

Patra T C, Pandey A K and Dutta H C 1996 Potential areas of coal seam methane in India; J. Geol. Soc. India 47 215-227.

Pophare A M and Varade A M 2004a Coal Bed Methane Exploration: A Case Study from Sawang Colliery, East Bokaro Coalfield, Jharkhand, India; Gond. Geol. Magz. 19(1) $37-55$.

Pophare A M and Varade A M 2004b Coal bed methane potential of coal seams in Sawang Colliery, East Bokaro Coalfields, Jharkhand, India; Indian J. Petroleum Geol. 13(1) 41-53.

Pophare A M and Varade A M 2006 Adsorption isotherm and petrographic studies of coal seams of Sawang area, East Bokaro Coalfield, Jharkhand, India; J. App. Geochem. 8(2A) 376-393.

Raja Rao C S 1987 Coalfields of India; Bull. Geol. Surv. India, A-IV 45(I) 60p.

Rice D D 1993 Composition and origins of coal bed gas; In: "Hydrocarbons from coal" (eds) Law B E and Rice D D, AAPG Studies in Geology 38 159-184.

Rightmire C T 1984 Coal bed Methane Resource of the United States; In: Rightmire C T, Eddy G E and Kirr J N (eds) AAPG Studies in Geology 17 1-13.
Shankaran V and Bastia R 1994 Coal seam methane: a frontier technology; Coal Expl. VI 40-48.

Sharma D D and Sundaram M S 2001 Evaluation of coal bed methane and its technology for exploration and production in India; In: Proc. Int. Seminar on "Coal Bed Methane - Prospects and Potentialities", South Asian Asso. Eco. Geologist 97-107.

Sharma N L and Ram K S V 1966 Introduction to the geology of coal and Indian coal fields; Oriental Publ., Jaipur $183 p$.

Varma A K and Mazumdar S K 2001 Cleat pattern Petrographic investigations of some coal seams in Jharia coalfield, India for coal bed methane; In: Proc. Int. Seminar on "Coal Bed Methane - Prospects and Potentialities", South Asian Asso. Eco. Geologist 131-140.

Yee D Seidle J P and Hanson W B 1993 Gas sorption on coal and measurement of gas content; In: "Hydrocarbons from coal" (eds) Law B E and Rice D D, AAPG Studies in Geology 38 203-218.

Yenigalla G R 2006 CBM-A new dimension to energy security, recovery in coal sector - A perspective. In: Varma A K, Venkatesh A S, Dhar Y R and Saxena V K (eds) "Frontier areas in geological and technological aspects of fossil fuels and mineral resources", ISM, Dhanbad, GTFM, 69-76. 